\title{
The Effect of Flipped Classroom Model Towards Students' Reading Comprehension
}

\author{
Yuvita Yuvita*, Endang Sulistyaningsih, Nissa Dhiya 'Ulhaq
}

\begin{abstract}
English Education Department, Universitas Pancasakti Tegal, Indonesia Corresponding author. Email: yuvieazfa@gmail.com
\end{abstract}

\begin{abstract}
The purpose of this paper was to determine whether the flipped classroom model has a beneficial effect on students' reading comprehension during their second semester at Universitas Pancasakti Tegal in the academic year 2020/2021. To accomplish this, a total of 39 students were randomly assigned to two equal groups of 17 students each: an experimental group (flipped classroom) and a control group (traditional classroom) (conventional online classroom). The author used the reading comprehension test as a pre-test for this two-group study. We used paired samples and independent samples t-tests to determine the effectiveness of flipped classrooms on students' reading comprehension. The paired and independent samples t-tests revealed a significant difference in post-test scores between the experimental and control groups. On the post-test, the experimental group significantly outperformed the control group $(\mathrm{p}<0.05)$. The study concluded that using a flipped classroom model had a significant positive effect on students' reading comprehension during the second semester of the English Department at Universitas Pancasakti Tegal.
\end{abstract}

Keywords: Flipped Classroom, Reading Comprehension

\section{INTRODUCTION}

Reading is one of the basic skills in English that students must learn because they are supposed to gain more knowledge, facts, and certain pleasures. Nation (2008), say that reading is thought to be the main source of English Foreign Language (EFL) information that can help students enhance their knowledge and discourse structure. In this case, the first consideration in the reading process is comprehension. The interaction between the reader's prior knowledge and understanding of the knowledge from the text is the basic factor for comprehension because reading without comprehension would not be able to comprehend the information contained in the text. Thus, reading comprehension is a crucial element facilitating students to gain more knowledge to increase their reading skills.

For higher education level students, learning English which their chosen should be a pleasurable experience compared to senior high school students where English is one of the subjects to be learned at school. The preliminary observation is conducted at the second-semester students of English Department Universitas Pancasakti Tegal. The findings show that students can read English material relatively well. In addition, some students participate actively in class while others participate passively. They are frequently bored with activities that are repetitive and excessively serious. They believe that having to do basic English assignments during learning activities not only annoys but also depresses them. As a result, they require a solution that is enjoyable, simple, and non-boring.

Changing the learning model by applying a new learning model is one thing that teachers often do to make learning activities more active and creative. In addition, with the occurrence of the current condition that nearly every higher education institution, teaching, and learning have been impacted by COVID-19, with reports that classroom instruction has been phased out in favor of distance education and learning [2]. In this state, teachers and students are being forced to adapt modern learning approaches by implementing online learning (e-learning). 
One form of action from schools in online classroom management is to develop learning technology and Learning Management System (LMS) include Google-Classroom, Ms. Teams, Edmodo, Moodle, or others. It is possible to increase the quality of teaching and learning by allowing students to create their learning and access a wider range of learning opportunities. One of the reasons for the rise in popularity of a modern learning approach known as student-centered learning.

Furthermore, the flipped classroom model is one of the learning models that is considered applicable when implementing online learning-based studentcentered learning. Bregmann and Sams (2012) who created this teaching technique stated in their book "Flip Your Classroom" that a flipped classroom in which learning activities or the art of learning (pedagogy) where students learn learning material through a learning video at home or before coming to class, while classroom activities will be used more for group discussions in solving problems, advancing concepts, engaging in collaborative learning, and questioning each other. [4] also explained that outside of the classroom, instructional material usually they can be accomplished by viewing a videotaped lecture, listening to podcasts, or conducting an internet search for subject information. Students bring their knowledge into the classroom and apply it through a variety of active learning activities, with the teacher acting as a facilitator and tutee.r. This model will encourage students to find their learning styles independently and grow their skills.

\section{REVIEW OF LITERATURE}

\subsection{Flipped Classroom}

A flipped classroom is essentially a role model requiring students to prepare for the course by viewing videos, reading an article, and listening to podcasts. The flipped classroom has emerged as an innovative technique that reverses the roles of homework and classroom activities. In the conventional learning concept, students get instructors and learn new content in their classes, such as through lectures and practice questions did as homework. In the flipped learning idea, students gain knowledge at home and carry out assignments at school such as by watching videos made by teachers and practicing skills in class [5].

There are several definitions of the flipped classroom in the literature. [3] who create this teaching technique stated in their book "Flip Your Classroom" that a flipped classroom in which learning activities or the art of learning (pedagogy) where students learn learning material through a learning video at home or before coming to class, while classroom activities will be used more for group discussions in solving solving problems, advancing notions, collaborating on learning, and discovering one another. They continue, "The flipped classroom approach is a system that provides a longer interaction time between the teacher and students, where students are responsible for their learning, the transition of the teacher's role to that of a guide, each student receives individual education, consistency of learning through repetition, and prevents students from missing a class who cannot come to class for any reason."

Bishop [6] explain that a flipped classroom is a student-centered learning method that incorporates interactive learning activities during class and individual instruction via computer outside of class.

The flipped classroom model as an instructional technique, according to [6], consists of two primary parts: namely the pre-classroom (or outside classroom) session, which consists of two stages: preparing the material and sharing the material, and the in-classroom (or inside classroom) session, which consists of two stages: reviewing the online material as well as guiding \& monitoring the collaborative work.

\subsection{Reading Comprehension}

Reading comprehension is defined as reading to comprehend the writer's entire message, including both main ideas and supporting details. Reading is a cognitive process that involves interacting with print and reviewing comprehension to determine what to mean [7]. It means that readers interact with print and absorb the message using prior knowledge paired with visual information. As a result, if a reader fails to interact with printed materials and monitor understanding, he or she will be unable to obtain the desired information.

Several types of reading are identified by Brown (2004).

\section{Perceptive Reading}

Letters, sentences, punctuation and other graphemic signs are all elements of longer discourse stretches in perception reading tasks. It is inferred that processing occurs from the bottom up.Selective Reading 
The evaluation procedures utilized are largely to blame for this categorization. To assess one's reading comprehension of lexical, grammatical, or conversational qualities of language over a short period of time, picturecued tests, matching, true/false, multiplechoice, and other common activities are utilized. Sentences, short paragraphs, and fundamental charts and graphs are examples of stimuli. Furthermore, concise responses are essential.

2. Interactive Reading

To maintain the processed material, an interactive task seeks to distinguish relevant aspects (lexical, symbolic, grammatical, and conversational) within reasonably brief texts. Such jobs typically require top-down processing, while bottom-up output may be required in some circumstances.

3. Extensive Reading

Rather than asking test-takers to "zoom in" on small information, the aim of the evaluation is typically to tap into a learner's overall comprehension of a document. For the most part, top-down processing is believed.

\subsection{Extensive Reading}

Reading is a source of knowledge and a source of pleasure. Reading, as a source of knowledge, can help students establish previously taught vocabulary and grammar, students learn new vocabulary and grammar, and it can inspire students to learn more and continue with their language studies through success in language use. Students' enjoyment of reading can increase as they improve their reading skills and fluency [1]. Therefore, extensive reading is given not only helps students learn to read in the target language, but also leads them to enjoy reading.

There are some activities in extensive reading for students to record their opinion while reading a book.

\section{Oral book report}

A student gives an oral book report to the class or a reading group in which he or she gives a commentary on a book. The goal of such reports is to persuade others to read the book rather than to give away the plot. These reports can be written in a certain structure, answering questions like what was the title of the book, what type of tale it was (mystery, love story, etc.), where and when it was set, how entertaining it was, and who would like to read it.

\section{Discussion group}

Learners who have already read the same book can participate in discussion groups. Four or five students should make up such a group. They may write an oral book report or a written review to present to the rest of the class as a consequence of their discussion. They then choose which book to discuss at their next meeting.

\subsection{Narrative Text}

The narrative is a type of genre that is used to entertain, inform, and deal with real or imagined events in a variety of ways. [9]. The narrative is mostly made up of fictional stories, but it can also be true at times. Fairy tales, fables, mysteries, stories, science fiction, romance, horror, and other forms are genres of narrative [10].

According to [10], narrative text has 5 elements of generic structures, they are:

1. Orientation

Orientation introduces who the character(s) was/were, where it occurred and when it occurred.

2. Complication

Complication tells the beginning of the problems which leads to the crisis (climax) of the character in the sequence story.

3. Resolution

This part tells the reader how the problems were solved either in a happy ending or in a sad (tragic) ending.

4. Re-orientation

This is an end-of-story statement that is optional. It is made up of the writer's moral lesson, advice, or teaching.

5. Evaluation

This part can be connected to the orientation component. It goes into more detail to make the story more clear and understood. However, readers may encounter more than one complication and resolution. It can happen if the problem (complication) in the scheme is still there or unaddressed. 


\subsection{Assessing Reading Activities}

\subsubsection{Retellings}

Table 1 Story Retelling Checklist

\begin{tabular}{|l|l|l|l|}
\hline Performance Tasks & Unprompted & Prompted & Comments \\
\hline Characters Name & & & \\
\hline Setting Description & & & \\
\hline Begins to retelling & & & \\
\hline $\begin{array}{l}\text { Identifies problem or } \\
\text { issues }\end{array}$ & & & \\
\hline $\begin{array}{l}\text { Identifies major events } \\
\text { Reports events in }\end{array}$ & & & \\
\hline Describes resolution & & & \\
\hline
\end{tabular}

O’Malley \& Pierce (1996) identify and describe instructional activities that can serve for reading assessment in a foreign language, one of them is retelling. When it comes to testing reading comprehension, retelling is far more effective than having students read aloud. In this case, teachers may emphasize pronunciation and intonation rather than reading comprehension when students read aloud. Teachers might give students story maps and checklists (see table 1) to help them in their retelling.

\subsubsection{Movie Review}

Students are asked by the teacher not only to watch some movies but also to review the movie. According to writing center Thompson Rivers University, a summary and analysis are included in a book review, just as they are in a movie review. Students should begin with an introduction, followed by a synopsis of the book/movie, an analysis, and a conclusion.

\section{METHODOLOGY}

The researcher employs a quantitative approach in this study. This is an experimental study in which the researcher wishes to ascertain the relationships between cause (dependent variables) and effect (independent variables).

A try-out is also conducted to a group of students to test its validity and reliability. The results show that the test is valid and reliable. After collecting data, the researcher uses SPSS Statistics 22 to interpret the experimental results in order to determine the effects of the Flipped Classroom Model on the teaching of reading comprehension.

\section{RESULT AND DISCUSSION}

\subsection{Result}

The research was conducted on May, 25th June, 25th 2021 during 4 meetings and 2 meetings 
for pre-test and post-test. The researcher used a two-group design, so there were two classes taught. In this research, the samples are taken by using purposive sampling. The researcher took 39 students from two classes that are similar in score. The first group which consists of 17 students as a sample is called the experimental group and the second group which consists of 17 students as a sample is called the control group. The first class is an experimental group that was taught by using flipped classroom model. The writer got class $2 \mathrm{~B}$ as an experimental group. The second class is the control group that was taught by the conventional online learning model. The control group was class 2A.

The students were given a pre-test and a posttest by the researcher to determine the result. Each reading test contained a total of 25 questions. A multiple-choice test was given to the students with a time limit of 45 minutes. The exam was held in a virtual setting utilizing Google Meets. Tests were given to the second-semester English department students, which included 17 students in class $2 \mathrm{~A}$ and 17 students in class $2 \mathrm{~B}$.

The implementation of the flipped classroom in teaching reading narrative text in the current study was described based on Bishop and Verleger, (2013). They proposed that the flipped classroom consists of two main parts, namely the preclassroom (or outside classroom) session, which consists of two stages: preparing the material and sharing the material, and the in-classroom (or inside classroom) session, which consists of two stages: reviewing the online material as well as guiding \& monitoring the collaborative work.

\subsubsection{Pre-classroom Session}

\subsubsection{Preparing The Material}

In preparing the material for the pre-classroom session, the writer was in charge of preparing the video, designing the PowerPoint materials, and reading texts and questions. To keep the students interested and avoid boredom, the writer appeared videos of materials which was less than 10 minutes long. The writer also admitted to using videos from the internet; in this case, the writer used YouTube videos. The writer chose narrative videos about Malin Kundang, Roro Jonggrang, Lutung Kasarung, The Queen, A Fox and A Cat, and Timun Mas in the first meeting, and the students had the option to watch one of the stories. For the second meeting, the writer used a movie video entitled Northanger Abbey by Jane Austen. Unlike the video, the writer created her slide presentation materials, which included explanations about a narrative text, extensive reading, and reading questions or tasks based on the needs of students, and learning objectives.

\subsubsection{Sharing the Material}

Following the preparation of the material, the writer proceeded to share it with the students. The writer uploaded the material on Edmodo which was created by the teacher specifically for the extensive reading class. The materials were shared with the writer two days before the meeting. Before the inclassroom session, the writer additionally instructed the students to complete and submit the reading task as well as the students' notes. Furthermore, the students were expected to take notes on what they did not fully comprehend from the shared materials.

\subsubsection{In-Classroom Session}

\subsubsection{Reviewing the Online Material}

For the in-classroom session, the writer reviewed the online material that had been distributed. Initially, the writer checked the students if there were students who did not study the material or submit tasks and found that there were students who did not submit tasks. The writer then found out their reason that they didn't do the task because they forgot and had other tasks to do. After checking, the writer reviewed the material provided with the students using Google meet and screen sharing to display the slide material, the writer reviewed the reading questions, student notes, and narrative and movie videos.

\subsubsection{Guiding and Monitoring Collaborative work (Giving activities for Students)}

In giving activities for students, the first meeting, the writer instructed the students to retell their chosen story which had been shared. The writer chose 6 students to retell the stories while the other students analyzed and commented actively. In this meeting, they were embarrassed to turn on the camera and the speaker in the class individually as representatives if they had a turn to retell a story. They needed more booster from the writer to perform in front of the class.

In the second meeting, the writer instructed the students to review a movie with an English subtitle entitled Northanger Abbey by Jane Austen. The control group was given a synopsis of the movie while the experimental group was given a movie video. The students in the experimental group were more active than the control group. But both groups 
still had trouble with the review task, they were confused about how to write a good movie review.

In the third meeting, the writer instructed the students to do tasks collaboratively on reviewing movies or stories. Since the total numbers of students in the class were 17 , the teacher divided them into 4 groups. Thus, 4 groups were consisting of 4 students, and 1 group consisting of 5 students. The writer also revealed that the teacher chose the leaders of the groups purposely. Then, the students need to discuss actively in the group WhatsApp about what movie or story they would choose. After they discussed, they presented the result of what movie or story they choose and the reason why they chose the movie or story.
After working collaboratively in a group, in the fourth meeting, the students were instructed to present their work in front of the class. In addition, the writer also explained that the writer also gave points to audiences who asked questions and gave commentary to the presenters, and provided them support and feedback regarding the learning or the materials. After all of the data were collected and processed, the paired and unpaired samples To determine the effectiveness of flipped classrooms on students' reading comprehension, t-tests were administered to second-semester English department students at Universitas Pancasakti Tegal. (see table 2 and 3 ).

Table 2 Group Statistic (Post-test Both of Groups)

\begin{tabular}{|l|l|r|r|r|r|}
\hline & Class & N & Mean & Std. Deviation & Std. Error Mean \\
\hline Post-test Result & PostEx & 17 & 84.47 & 11.906 & 2.888 \\
& PostCon & 17 & 72.94 & 17.974 & 4.359 \\
\hline
\end{tabular}

Table 3 Independent Samples T-test (Post-test Both of Groups)

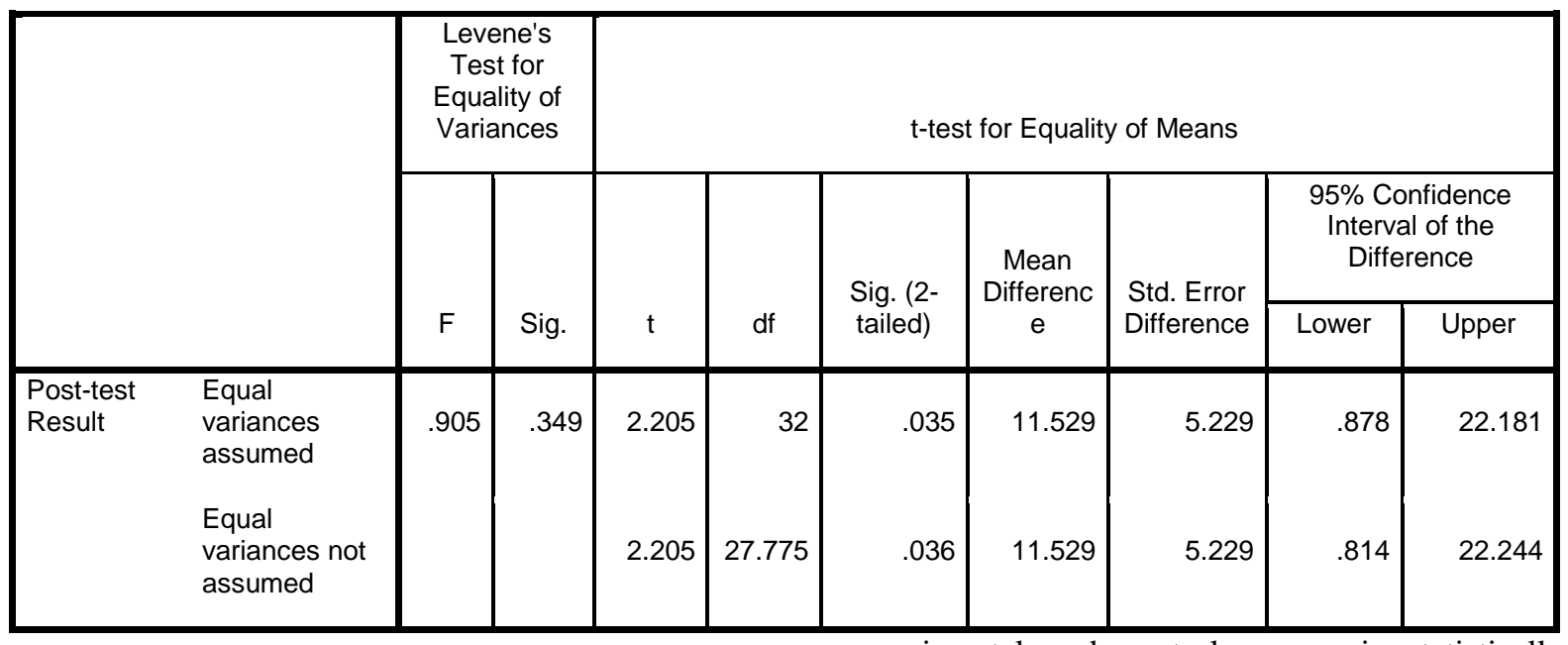

The descriptive statistics for both groups are shown in Table 2. The groups' means vary. The experimental group's mean score is 84,47 , while the control group's mean score is 72,94 . In this study, it can be concluded that the experimental group outperformed the control group.

Given that the Sig. (2-tailed) value for the independent samples t-test is $0,035<0,05$, it can be concluded that the difference between the experimental and control groups is statistically significant at $(\mathrm{p}<0,05)$.

From the findings above, the experimental group outperformed the control group by a significant margin $(\mathrm{p}<0.05)$ on the post-test. H0 is rejected and $\mathrm{H} 1$ is accepted. So it can be concluded that there is a significant positive effect of using flipped classroom model on students' reading comprehension at the second semester of English Department Universitas Pancasakti Tegal in the academic year of 2020/2021. 


\subsection{Discussion}

The focus of the classroom observation is to investigate the teaching and learning process of using a conventional online model to teach narrative text reading. The writer is immediately involved in the teaching and learning process in the reading class via Google Meet in conducting the observation on May $25^{\text {th }}, 2021$. As a result, it is apparent that various problems with conventional online learning have arisen, including:

1. The majority of the students' responses to the teacher's questions and explanations are passive.

2. The students are unmotivated, and they do not pay attention to the teacher, the reading text, or the material discussion session.

3. They forget what they learned before.

4. A lack of vocabulary among students, causing the topic, reading materials, and teacher explanations to be misunderstood.

5. Limited study time, due to different technological constraints provided by the online learning system, materials, readings, and explanations are not adequately transmitted.

The flipped classroom model is used as a solution to the online learning model focused on student-centered learning to overcome the problems that arise. The data analysis for the implementation of the flipped classroom in teaching reading narrative text in this study is described based on Bishop and Verleger (2013).

The writer uses independent samples t-tests and paired samples t-tests to determine the effect of flipped classrooms on students' reading comprehension. Students who received instruction in flipped classrooms outperformed those who received instruction in vocational classrooms. As can be seen, the experimental group's mean was 77,65 at pre-test and 84,47 at post-test. The control group's mean was 83,76 in the pre-test and 72,94 in the post-test. This means that in this study, the experimental group outperformed the control group. On the posttest of reading comprehension, the experimental groups have a significantly higher mean than the control groups.

As the primary limitation of the present study, it may be claimed that the flipped classroom relies on student engagement and that one has to trust students to watch videos or materials at home. Unfortunately, there is no way to guarantee that students will follow the flipped classroom model or comply with it, and students who do not watch the videos or study at home may be unprepared in class. Inequities in students' home lives can also be a major obstacle for the flipped classroom model. Some students are unable to access the technology required to observe or engage with teachers in virtual classes because they do not have a strong signal.

\section{CONCLUSION}

The teacher prepared online materials and shared them with the students during the preclassroom session using Edmodo as the media of learning outside the classroom. Sharing the material stage also included assigning reading questions to students and taking notes from them. The teacher examined the online materials that had already been shared in the classroom session and provided feedback based on the students' activities and collaborative work during the in-class session.

According to the findings, second-semester students of the English department Universitas Pancasakti Tegal got benefit from flipped classroom model which provided interesting experiences, such as teacher-student interaction, providing some videos before the in-class session, collaborative work, discussion, and evaluation from the teacher. It might be argued that getting instruction through the use of flipped classrooms could help students learn English more quickly and be more independent in learning on their outside of the classroom.

The author suggest several points, First, Teachers could create new and personalized ways to increase the flipped model's effectiveness in their classrooms and modify it to address the condition, needs, and interests of their students. Second, Students should be given additional time to practice reading at home as well as at school.

Third, future researchers will conduct in-depth research on the flipped classroom model's effect on other language skills such as writing, listening, and speaking.

\section{REFERENCES}

[1] Bergmann, J., \& Sams, A. (2012). Flipped Your Classroom: Reach every student in every class every day. (First Ed.). Washington, DC; Alexandria, VA: ISTE; ASCD.

[2] Bishop, J. L., \& Verleger, M. A. (2013). The flipped classroom: A survey of the research. ASEE Annual Conference and Exposition, Conference Proceedings, (August). https://doi.org/10.18260/1-2--22585 
[3] Brown, C. A., Danvers, K., \& Doran, D. T. (2016). Student perceptions on using guided reading questions to motivate student reading in the flipped classroom. Accounting Education, 25(3), 256-271. https://doi.org/10.1080/09639284.2016.11651 $\underline{24}$

[4] Clarke, M. A., \& Silberstein, S. (1977). Toward a Realization of Psycholinguistic Principles in the ESL Reading Class. Language Learning, $27(1)$,

135-154.

https://doi.org/10.1111/j.14671770.1977.tb00297.x

[5] Hartono, R. (2005). Genres of texts. Semarang: English Department, Faculty of Language and Art: Semarang State University.

[6] Marinoni, G., Land, H. Van, \& Jensen, T. (2020). The Impact Of Covid-19 On Higher Education Around The World IAU Global Survey Report. Retrieved from https://www.iau-

aiu.net/IMG/pdf/iau_covid19 and he survey _report_final_may_2020.pdf

[7] Nation, I. S. P. (2008). Teaching ESL/EFL Reading and Writing (ESL \& Applied Linguistics Professional Series). Retrieved from http://www.amazon.com/TeachingReading-Writing-LinguisticsProfessional/dp/041598968X

[8] O’Malley, J. M., \& Pierce, L. V. (1996). Authentic Assessment for English Language Learners (C. Sisca, Ed.). United States of America: Longman.

[9] Sulistyo, I. (2013). An Analysis of Generic Structure of Narrative Text. ETERNAL (English Teaching Journal), 4(2), 169-181. Retrieved from http://journal.upgris.ac.id/index.php/eternal/art $\underline{\text { icle/view/1956 }}$ 